J. Perinat. Med. $11(1983) 19$

\title{
Pregnancy-specific $\beta_{1}$-glycoprotein $\left(\mathrm{SP}_{1}\right)$ in serum from women with pregnancies complicated by intrauterine growth retardation
}

\author{
L. Tamsen*, S. G. O. Johansson**, O. Axelsson* \\ * Department of Obstetrics and Gynecology, University Hospital, Uppsala, Sweden \\ ** Department of Clinical Immunology, Karolinska Hospital, Stockholm, Sweden
}

At present there is no universally accepted definition of intrauterine growth retardation (IUGR). In this report IUGR infants are defined as those with a birth weight below -2 SD of the normal mean for the gestational age [7]. These infants have a high perinatal mortality [21] and morbidity [11]. For detection of IUGR both the "gravidogram" [29] and ultrasound examination [23] have been found to be effective methods.

For monitoring of already diagnosed or suspected cases of IUGR the concentrations of several products of the fetus and/or the placenta have been measured in maternal blood or urine. Among the most frequently evaluated for this purpose have been estriol [17] and human placental lactogen (HPL) [16].

During the last 10 years many additional biochemical markers have been identified. One of them is pregnancy-specific $\beta_{1}$-glycoprotein $\left(\mathrm{SP}_{1}\right)$ [2], which is a placental product [12]. During late pregnancy the serum concentration of $\mathrm{SP}_{1}$ correlates with infant birth weight and placental weight both in uncomplicated and in complicated pregnancies $[24,26,28]$.

Previous reports have indicated that $\mathrm{SP}_{1}$ seems promising as a predictor of IUGR $[8,25,28]$. The aim of the present study was to examine the possibility of detecting and monitoring IUGR from $\mathrm{SP}_{1}$ concentrations in maternal serum, measured by nephelometry, during pregnancy weeks 29 to 40 . The $\mathrm{SP}_{1}$ values obtained were compared with a reference range of serum $\mathrm{SP}_{1}$

\section{Curriculum vitae}

LAILA TAMSEN, born in 1942, M.D. 1971, Specialist in Obstetrics and Gynecology 1977. At present registered physician, Department of Obstetrics and Gynecology, University Hospital, Uppsala, Sweden.

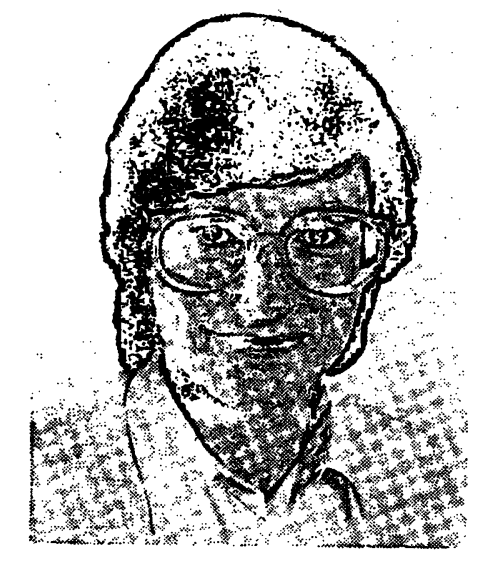

levels in uncomplicated single pregnancies from a cross-sectional study [24] and with serial values from individual women with uncomplicated single pregnancies.

\section{Material and methods}

Thirty-seven women in pregnancy weeks 29 to 40 , all of whom subsequently gave birth to single IUGR infants, volunteered for this study. A total of 67 blood samples were obtained for $\mathrm{SP}_{1}$ analyses. The women were 19 to 42 years old (mean 27 years). Twenty-three women were primiparous and 14 were multiparous. Detailed clinical data on these women are given in Tab. I. Preeclampsia was diagnosed and classified according to the criteria of the U.S. Comittee on Maternal Welfare issued in 1952 [18]. The WHITE classification was used for diabetes mellitus [19]. 
Tab. I. Clinical grouping of 37 women with pregnancies complicated by intrauterine growth retardation (infant birth weight below $-2 \mathrm{SD}$ of the normal mean for the gestational age) [7].

\begin{tabular}{llcc}
\hline Group & $\begin{array}{l}\text { APGAR score at } 1 \text { minute } \\
\leqslant 6\end{array}$ & Total \\
\hline $\begin{array}{l}\text { No maternal } \\
\text { complication }\end{array}$ & 1 & 11 & 12 \\
\hline $\begin{array}{l}\text { Pre-eclampsia } \\
\text { levis }\end{array}$ & $3^{+*}$ & $6 *$ & 9 \\
\hline $\begin{array}{l}\text { Pre-eclampsia } \\
\text { gravis }\end{array}$ & 5 & 2 & 7 \\
\hline $\begin{array}{l}\text { Diabetes } \\
\text { mellitus } \\
\text { group D } \\
\text { group F }\end{array}$ & $1 * *$ & & \\
\hline $\begin{array}{l}\text { Miscellaneous } \\
1\end{array}$ & 1 & $6 * *$ & 1 \\
\hline \begin{tabular}{l} 
Total \\
\hline
\end{tabular} & 11 & 26 & 7 \\
\hline
\end{tabular}

1) essential hypertension, pre-partum hemorrhage, premature rupture of the membranes, ulcerative colitis, cervical insufficiency, congenital malformation

+ two stillborns

* one pre-partum hemorrhage

** one lethal congenital malformation

Cesarean sections were performed on 19 women from pregnancy weeks 29 to 41 because of maternal and/or fetal complications. In all, 10 infants were born before the 35 th week of pregnancy.

Induced or spontaneous vaginal labor occurred in pregnancy weeks 36 to 42 except in three cases, where stillborn infants were delivered in weeks 30 to 36 of pregnancy, one with a lethal congenital malformation. Another infant died later from lethal congenital malformation.

From 21 women with uncomplicated single pregnancies giving birth to healthy infants of normal birth weight [7] in pregnancy weeks 38 to 42,210 blood samples were collected weekly or biweekly.

Serum or plasma was stored at $-20^{\circ} \mathrm{C}$ until assayed.

Nephelometry was performed as described elsewhere [24]. The interassay variation was $5 \%$ and the detection limit $0.5 \mathrm{mg} / 1$. No differences were found between plasma and serum concentrations of $\mathrm{SP}_{1}$ [24]. Whether the analyses were performed on plasma or serum, the term "serum concentration" will be used in the following.
The reference range of serum $\mathrm{SP}_{1}$ concentrations for uncomplicated single pregnancies used for comparison with the $\mathrm{SP}_{1}{ }^{1}$ values obtained is the same as previously described [24].

\section{Results}

The $\mathrm{SP}_{1}$ values in 67 blood samples from 37 women with single pregnancies complicated by IUGR are illustrated in Fig. 1. Most of the values

\section{$\mathrm{SP}_{1}, \mathrm{mg} / \mathrm{l}$}

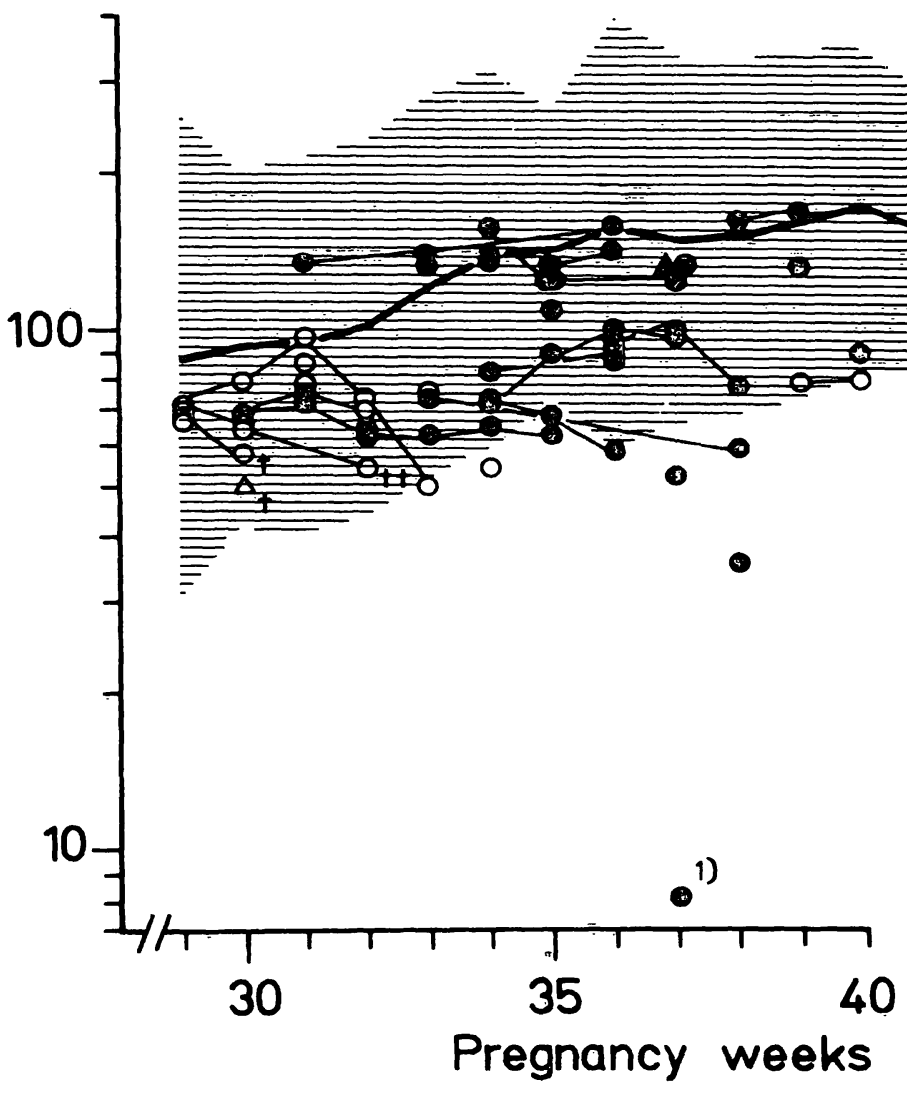

Fig. 1. Pregnancy-specific $\beta_{1}$-glycoprotein $\left(\mathrm{SP}_{1}\right)$ levels measured by nephelometry in serum from 37 women (67 samples) with single pregnancies complicated by intrauterine growth retardation (infant birth weight below $-2 \mathrm{SD}$ of the normal mean for the gestational age) [7].

The shaded area represents a $95 \%$ reference range for $\mathrm{SP}_{1}$ levels in uncomplicated single pregnancies obtained from a cross-sectional study of 323 women [24j, and the solid line is the geometric mean.

The following symbols are used: APGAR score at 1 minute $\geqslant 7(\bullet)$, idem $\leqslant 6(0)$, an infant with acrania and other malformations $(\Delta)$, an infant with ZELLWEGER's syndrome (A), an infant stillborn in pregnancy week 30 $(+)$ and one stillborn in pregnancy week $35(++)$.

The woman with an extremely low $\mathrm{SP}_{1}$ value [1] had a normal value of human placental lactogen. 
were below the geometric mean of the reference group and serial samples showed a tendency to a decrease in $\mathrm{SP}_{1}$ levels, which was more marked when the APGAR score at $1 \mathrm{~min}$ was low.

A serum $\mathrm{SP}_{1}$ value of $80 \mathrm{mg} / 1$ (approximately corresponding to the geometric mean - 1SD) was chosen as the most appropriate discriminatory level between uncomplicated pregnancies and pregnancies complicated by IUGR in gestational weeks 32 to 34 . The distributions of the initial $\mathrm{SP}_{1}$ values among women with IUGR infants and those with uncomplicated pregnancies in relation to the $80 \mathrm{mg} / \mathrm{l}$ level were compared and the results are given in Table II. Of 15 women with

$\mathrm{SP}_{1}, \mathrm{mg} / \mathrm{l}$

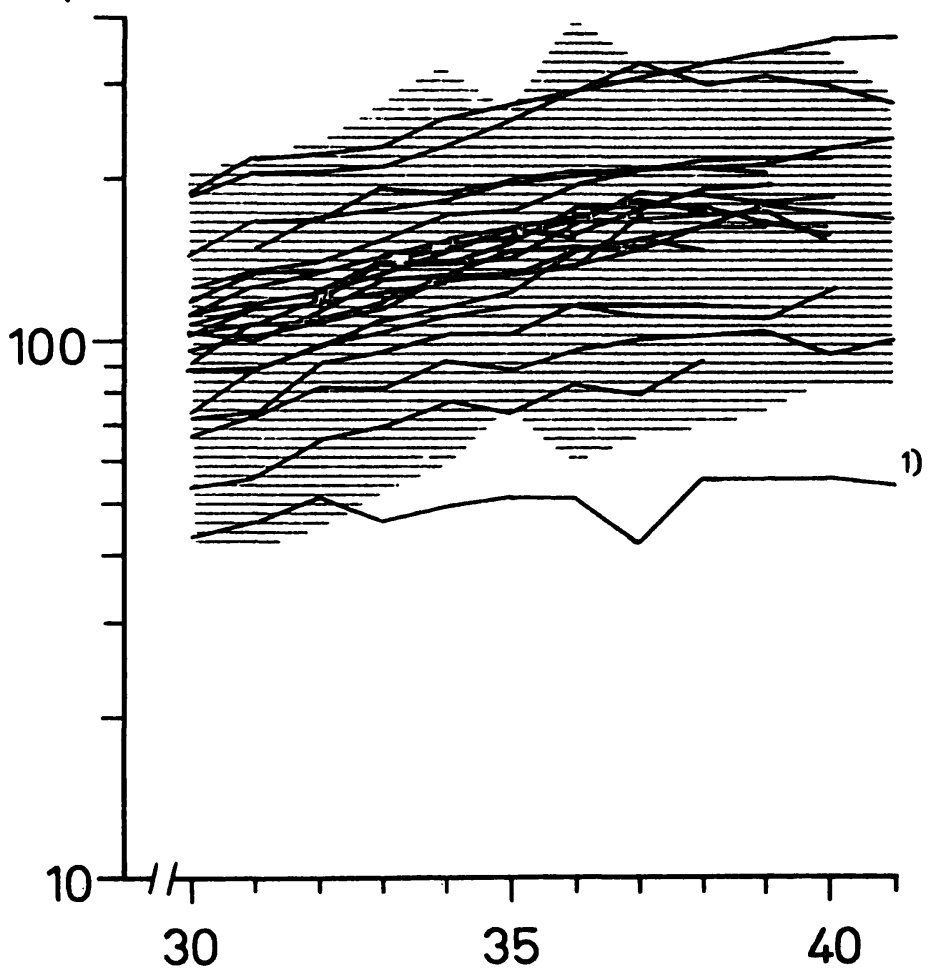

\section{Pregnancy weeks}

Fig. 2. Pregnancy-specific $\beta_{1}$-glycoprotein $\left(\mathrm{SP}_{1}\right)$ levels measured by nephelometry in serum from 21 women with uncomplicated single pregnancies (total 210 samples). The infants were born in pregnancy weeks 38 to 42 and were healthy and of normal weight (mean $\pm 2 \mathrm{SD}$ for the gestational age) [7].

The shaded area represents a $95 \%$ reference range for $\mathrm{SP}_{1}$ levels in uncomplicated single pregnancies obtained from a cross-sectional study of 317 women [24].

1) This woman had normal serum values of alpha-fetoprotein, estriol and human placental lactogen.
IUGR infants, $10(67 \%)$ had a serum $\mathrm{SP}_{1}$ value below $80 \mathrm{mg} / \mathrm{l}$, while the corresponding figure for uncomplicated pregnancies was 10 out of 76 women (13\%).

The $\mathrm{SP}_{1}$ values in serial samples from 21 women with uncomplicated pregnancies are presented in Fig. 2. From pregnancy weeks 30 to 36 there was a steady increase in the $\mathrm{SP}_{1}$ concentration and after week 36 there was a tendency to a plateau. Using the function for linear regression $\log y=a x+b$, where $y=S P_{1}$ value and $x=$ pregnancy week, two average linear developments were determined (Fig. 3). The mean increase in the $\mathrm{SP}_{1}$ concentration from pregnancy weeks

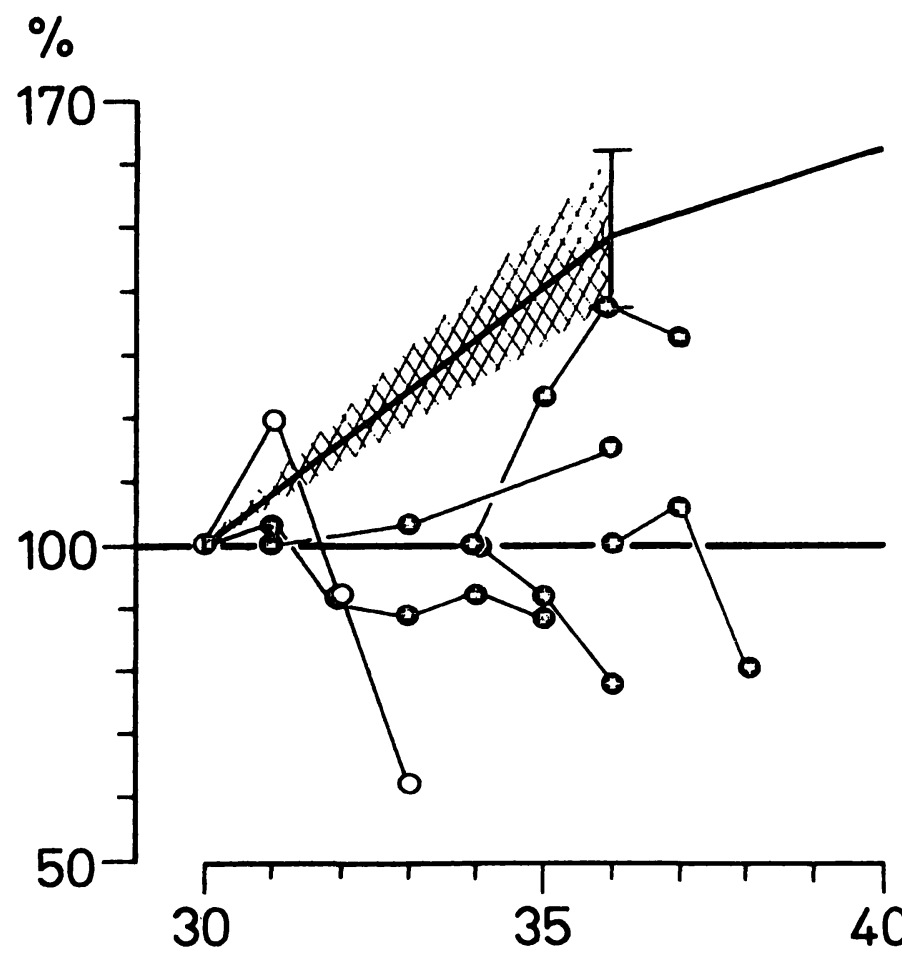

\section{Pregnancy weeks}

Fig. 3. The mean increase $\pm 1 \mathrm{SD}$ (solid line and shaded area) in the serum concentration of pregnancy-specific $\beta_{1}$-glycoprotein $\left(S P_{1}\right)$, measured by nephelometry, in serial samples from 21 women with uncomplicated single pregnancies in pregnancy weeks 30 to 36 , in percent of the initial value. The mean increase of the $\mathrm{SP}_{1}$ concentration is continued for pregnancy weeks 36 to 40 .

The developments of the $\mathrm{SP}_{1}$ levels in serum from six women with pregnancies complicated by intrauterine growth retardation (infant birth weight below - 2 SD of the normal mean for the gestational age) [7] are also shown. Serial samples from each woman are connected with a solid line; open circles represent an APGAR score or $\leqslant 6$ at $1 \mathrm{~min}$ and closed circles an APGAR score of $\geqslant 7$ at $1 \mathrm{~min}$. 
30 to 36 was $49 \%$. During weeks 36 to 40 the mean increase was $13 \%$.

The $\mathrm{SP}_{1}$ values in serum from six women with IUGR infants from whom at least three serial samples were drawn over a period of at least two weeks showed a decreasing tendency (Fig. 3.). The decline was most marked in the woman whose infant had a low APGAR score at $1 \mathrm{~min}$ after birth.

\section{Discussion}

As the etiology of IUGR is multifactorial [15], no single abnormal clinical or biochemical finding is sufficient in itself for diagnosis and intervention. Reliable diagnosis of this condition and/or monitoring of already diagnosed IUGR must depend upon a combination of clinical and laboratory approaches [9] as well as on an accurate estimation of gestational age. If there is any doubt about the length of a pregnancy, an early ultrasound examination will give correct dating [3]. With reliable dating, the simple "gravidogram" can be used as a routine examination and $75 \%$ of infants of low birth weight for their gestational age can be detected [29]. An ultrasound examination measuring the biparietal diameter and the body circumference [23] can confirm suspected growth retardation.

However, even if the fetus and the placenta together form one entity, the causes of IUGR can be mainly fetal (e.g. congenital malformation) or purely placental [15]. It might therefore be of value to combine at least two biochemical markers that mainly depend on the status of either the fetus or the placenta.

Of the placental proteins, HPL is the hitherto most frequently evaluated in different complications during late pregnancy [14]. Like $\mathrm{SP}_{1}$, it has a low day-to-day variation, but the concentration of HPL in maternal serum is about $20-30$ times lower than that of $\mathrm{SP}_{1}$ [27] and for analyses of HPL a sensitive method such as a radioimmunoassay or an enzyme immunoassay has to be used. $\mathrm{SP}_{1}$, however, is easily measured by simple immunoprecipitation methods or nephelometry [24].
In earlier studies in which $\mathrm{SP}_{1}$ was compared with $\mathrm{HPL}$, the predictive value of $\mathrm{SP}_{1}$ for IUGR was found to be equally good' as [22] or even better than that of HPL [28].

In the present investigation it was found that a serum $\mathrm{SP}_{1}$ level below $80 \mathrm{mg} / 1$ in a single blood sample drawn in pregnancy weeks 32 to 34 had a predictive value of $50 \%$ for IUGR and that a level above or at $80 \mathrm{mg} / 1$ had a value of $93 \%$ for predicting a normal infant birth weight (Tab. II). In this study IUGR infants were defined as those with a birth weight below -2 SD of the normal mean for the gestational age [7]. Even if other reports define IUGR as a birth weight below the 10th percentile of normal infant birth weight for the gestational age, it would seem of interest to compare our results with those of other studies. CHAPMAN et al. [5] used a serum $\mathrm{SP}_{1}$ value of $100 \mathrm{mg} / \mathrm{l}$ as a cut-off level in pregnancy weeks 31 to 34 and found a predictive value of $24 \%$ for

Tab. II. Sensitivity and predictive value of a single value of pregnancy-specific $\beta_{1}$-glycoprotein $\left(\mathrm{SP}_{1}\right)$ in serum, with $80 \mathrm{mg} / \mathrm{l}$ as the discriminatory level between uncomplicated pregnancies and pregnancies complicated with IUGR (infant birth weight below -2 SD of the normal mean for the gestational age [7]). The $\mathbf{S P}_{1}$ levels in the first blood samples drawn in pregnancy weeks 32 to 34 from 15 women were compared with the $\mathrm{SP}_{1}$ levels from a cross-sectional study of uncomplicated single pregnancies [24] for the same period.

$\mathrm{n}=$ number of women

$\mathrm{TP}=$ true positive and $\mathrm{FP}=$ false positive, i.e. $S P_{1}$ level $=\geqslant 80 \mathrm{mg} / 1$.

$\mathrm{TN}=$ true negative and $\mathrm{FN}=$ false negative, i.e. $\mathrm{SP}_{1}$ level $<80 \mathrm{mg} / 1$.

\begin{tabular}{lll}
\hline & $\begin{array}{l}\text { IUGR } \\
(\mathrm{n})\end{array}$ & $\begin{array}{l}\text { Uncomplicated } \\
\text { pregnancy }(\mathrm{n})\end{array}$ \\
\hline $\begin{array}{l}\mathrm{SP}_{1} \text { level } \\
<80 \mathrm{mg} / \mathrm{l}\end{array}$ & 10 & 10 \\
\hline $\begin{array}{l}\mathrm{SP}_{1} \text { level } \\
\geqslant 80 \mathrm{mg} / 1\end{array}$ & 5 & 66 \\
\hline Total & 15 & $76 \ldots$ \\
\hline Sensitivity & $\frac{\mathrm{TN}}{\mathrm{TN}+\mathrm{FP}}=66.7 \%$ & $\frac{\mathrm{TP}}{\mathrm{TP}+\mathrm{FN}}=86.8 \%$ \\
\hline Predictive value & $\frac{\mathrm{TN}}{\mathrm{TN}+\mathrm{FN}}=50 \%$ & $\frac{\mathrm{TP}}{\mathrm{TP}+\mathrm{FP}}=92.9 \%$ \\
\hline
\end{tabular}


IUGR. GORDON et al. [8] reported that during pregnancy weeks 31 to 40 more than $70 \%$ of women with IUGR infants had $\mathrm{SP}_{1}$ concentrations below the 10th percentile of the reference range. TOWLER et al. [28] found the predictive value of $\mathrm{SP}_{1}$ levels below a $95 \%$ reference range for detection of IUGR to be $60 \%$ during the last trimester. Thus, despite differences in the definition of IUGR and in the selection of reference ranges, the predictive values of the serum $\mathrm{SP}_{1}$ level for IUGR are in the same range.

During uncomplicated single pregnancies, there was an average increase of $49 \%$ in the $\mathrm{SP}_{1}$ concentration from pregnancy weeks 30 to 36 as assessed from serial samples from individual women (Fig. 3). It was also found that each individual woman maintained a certain concentration level throughout late pregnancy, i.e. they all showed the same relative increase but at individual levels. In serial samples from women with IUGR infants there was no such increase and even a decrease occurred (Fig. 3), a finding indicating that serial measurements of $\mathrm{SP}_{1}$ can be used for monitoring cases of suspected IUGR. An absence of an increase in the $\mathrm{SP}_{1}$ concentration, or the occurrence of a decrease, will strengthen the suspicion of IUGR. Besides, very low values or an early decrease seem to correlate with a low APGAR score.

One woman with an IUGR infant had an extremely low serum $\mathrm{SP}_{1}$ value (Fig. 1). A similar case has only been reported once [10], suggesting a rare and specific defect in the $\mathrm{SP}_{1}$ synthesis, as both these women had normal HPL values. It is of interest to note that a similar rare deficiency has been reported for HPL in cases with a normal pregnancy and delivery. In these cases the $\mathrm{SP}_{1}$ values were normal $[1,6,20]$. An immunosuppressive effect of $\mathrm{SP}_{1}$ has been found in studies in vitro $[4,13]$, which could indicate that $\mathrm{SP}_{1}$ has a function as an immunological protector of the pregnancy against the mother, but the findings of very low $\mathrm{SP}_{1}$ values in rare cases might cast some doubt on this suggestion.

In pregnancies complicated by congenital malformations combined with IUGR (Fig. 1) no special pattern of $\mathrm{SP}_{1}$ values was found as compared with the reference group of uncomplicated pregnancies. This finding is interesting. A normal serum $\mathrm{SP}_{1}$ value in a woman with an IUGR infant could point towards a fetal cause of the growth retardation, e.g. congenital malformation.

It is concluded that $\mathrm{SP}_{1}$ measurements are valuable adjuncts to the "gravidogram" and ultrasonar examination for the detection and monitoring of IUGR. As the day-to-day variation of $\mathrm{SP}_{1}$ is low, as is the methodological variation of nephelometry, a determination of $\mathrm{SP}_{1}$ in a single sample is in most cases sufficient to detect pregnancies at risk of IUGR in the beginning of the last trimester. Serial determinations will increase the predictive value even further.

\section{Summary}

Serum concentrations of pregnancy-specific $\beta_{1}$-glycoprotein $\left(\mathrm{SP}_{1}\right)$ were measured by nephelometry in 37 women with single pregnancies complicated by intrauterine growth retardation (IUGR). Sixty-seven blood samples were examined for their contents of $\mathrm{SP}_{1}$ in pregnancy weeks 29 to 40 . The $\mathrm{SP}_{1}$ values were compared with those obtained in a cross-sectional study of 323 women and a serial study of 21 women (210 samples) with uncomplicated single pregnancies.

It was found that a serum $\mathrm{SP}_{1}$ value below $80 \mathrm{mg} / 1$ in a single blood sample drawn in pregnancy weeks 32 to 34 had a predictive value of $50 \%$ for IUGR and a value above or at $80 \mathrm{mg} / 1$ had a value of $93 \%$ for predicting a normal infant birth weight.

Serial samples from individual women with uncomplicated single pregnancies showed an average increase in the $\mathrm{SP}_{1}$ concentration of $49 \%$ from pregnancy weeks 30 to 36. In serial samples from six women with IUGR infants there was no such increase, or a decrease occurred. It is concluded that $\mathbf{S P}_{1}$ measurements in maternal serum are valuable for the detection and monitoring of pregnancies complicated by IUGR.

Keywords: Fetal growth retardation, human pregnancy, nephelometry, placental function tests, pregnancy proteins, $\mathrm{SP}_{1}$. 


\section{Zusammenfassung}

Schwangerschaftsspezifisches $\beta_{1}$-Glukoprotein $\left(\mathrm{SP}_{1}\right)$ im mütterlichen Serum bei Schwangerschaften mit intrauteriner Mangelentwicklung

Bei 37 Frauen mit Einzelschwangerschaften, kompliziert durch intrauterine Mangelentwicklung, wurden nephelometrisch die Serumkonzentrationen des schwangerschaftsspezifischen $\beta_{1}$-Glukoproteins $\left(\mathrm{SP}_{1}\right)$ bestimmt. In 67 Blutproben wurde der $\mathrm{SP}_{1}$-Gehalt in der 29- bis 40 . Schwangerschaftswoche bestimmt. Als Vergleich zu diesen $S_{1} P_{1}$-Werten dienten die Ergebnisse einer Reihenuntersuchung an 323 Frauen und die Serienuntersuchungen an 21 Frauen (mit 210 Einzelproben), bei denen Einzelschwangerschaften komplikationslos verlaufen waren. Wir fanden, daß eine $\mathrm{SP}_{1}$-Konzentration $<80 \mathrm{mg} / 1-$ bestimmt in der 32 . bis 34 . Schwangerschaftswoche - einen prognostischen Wert von $50 \%$, eine $\mathbf{S P}_{1}$-Konzentration $\geqslant 80 \mathrm{mg} / 1$ einen proghostischen Wert von $93 \%$ für ein normales Geburtsgewicht des Kindes hat.

Serienuntersuchungen einzelner Frauen mit komplikationslosen Einzelschwangerschaften zeigten zwischen der 30. bis 36. Schwangerschaftswoche eine durchschnittliche Zunahme der $S P_{1}$-Konzentration um $49 \%$. Serienuntersuchungen an 6 Frauen mit intrauterin mangelentwickelten Kindern ließen diese Zunahme nicht erkennen, hier trat im Gegenteil eine Abnahme ein. Wir schließen aus unseren Ergebnissen, daß $\mathrm{SP}_{1}$-Bestimmungen in regelmäßigen Abständen ein wertvoller Parameter für die Erkennung und Verlaufskontrolle von Schwangerschaften mit intrauterin mangelentwickeltem Kind sind.

Schlüsselwörter: Fetale Wachstumsretardierung, Nephelometrie, Plazentafunktionstest, schwangerschaftsspezifische Proteine, $\mathbf{S P}_{\mathbf{1}}$.

\section{Résumé}

Glycoprotein $\beta_{1}\left(\mathrm{SP}_{1}\right)$ spécifique de la grossesse dans le sérum de femmes dont la grossesse est compliquée d'un retard de croissance intra-uterin

Des concentrations de glycoprotéine $\left(\mathrm{SP}_{1}\right)$, spécifique de la grossesse, ont été mesurées par néphélométrie chez 37 femmes présentant des grossesses uniques compliquées de retard de croissance intra-utérin (RCIU), 67 prélèvements de sang ont été analysés pour déterminer le taux de $\mathbf{S P}_{1}$ de la 29 ème à la 40 ème semaine de grossesse. Les taux de $\mathrm{SP}_{1}$ relevés ont été comparés à ceux obtenus par l'étude d'un groupe de 323 femmes et l'étude sérielle de 21 femmes (210 prélèvements) présentant des grossesses uniques normales.

Il a été mis en évidence qu'un taux de sérum $\mathrm{SP}_{1}$ inférieur à $80 \mathrm{mg} / 1$ dans un seul prélèvement sanguin effectué de la 32ème à la 34ème semaine de grossesse avait une valeur diagnostique de $50 \%$ pour un RCIU et qu'un taux égal ou supérieur à $80 \mathrm{mg} / 1$ permettait de diagnostiquer à $93 \%$ un poids de naissance normal.

Des prélèvements périodiques effectués individuellement sur des femmes présentant une grossesse simple sans complications ont montré une augmentation moyenne de la concentration de $\mathrm{SP}_{1}$ de $49 \%$ de la 30 ème à la 36 ème semaine de grossesse. Lors d'une série de prélèvements effectués sur des femmes présentant un RCIU, il n'a été constaté ni augmentation, ni dimination.

En conclusion, les mesures de $\mathrm{SP}_{1}$ effectuées sur le sérum maternel jouent un rôle important dans la détection et la surveillance des grossesses compliquées de RCIU.

Mots-clés: Grossesse, néphélométrie, protéines de la grossesse, retard de croịsance foetal, $\mathrm{SP}_{1}$, tests de fonction placentaire.

Acknowledgements: This study was supported financially by the Medical Faculty of the University of Uppsala, the Swedish Medical Research Council (grant no. 16X-105) and Föreningen Margarethahemmet, Knivsta, Sweden.

\section{Bibliography}

[1] ALEXANDER, I., F. ANTHONY, A. T. LETCHWORTH: Placental protein profile and glucose studies in a normal pregnancy with extremely low levels of human placental lactogen. Case report. Brit. J. Obstet. Gynaec. 89 (1982) 241

[2] BOHN, H.: Nachweis und Charakterisierung von Schwangerschaftsproteinen in der menschlichen Plazenta, sowie ihre quantitative immunologische Bestimmung im Serum schwangerer Frauen. Arch. Gynecol. 210 (1971) 440

[3] CAMPBELL, S., G. B. NEWMAN: Growth of the fetal biparietal diameter during normal pregnancy. J. Obstet. Gynaecol. Brit. Cwlth. 78 (1971) 513
[4] CERNI, C., G. TATRA, H. BOHN: Immunosuppression by human placental lactogen (HPL) and the pregnancy-specific $\beta_{1}$-glycoprotein (SP-1). Arch. Gynecol. 223 (1977) 1

[5] CHAPMAN, M. G., R. T. O'SHEA, W. R. JONES, R. HILlIE R: Pregnancy-specific $\beta_{1}$-glycoprotein as a screening test for at-risk pregnancies. Amer. J. Obstet. Gynec. 141 (1981) 499

[6] GAEDE, P., D. TROLLE, H. PEDERSEN: Extremely low placental lactogen hormone (HPL) values in an otherwise uneventful pregnancy preceding delivery of a normal baby. Acta Obstet. Gynecol. Scand. 57 (1978) 203 
[7] ENGSTRÖM, L., G. STERKY: Standardkurvor för vikt och längd hos nyfödda barn. Läkartidningen 63 (1966) 4922

[8] GORDON, Y. B., J. G. GRUDZINSKAS, D. JEFFREY, T. CHARD, A. T. LETCHWORTH: Concentrations of pregnancy-specific $\beta_{1}$-glycoprotein in maternal blood in normal pregnancy and in intrauterine growth retardation. Lancet I (1977) 331

[9] GORDON, Y. B., J. D. LEWIS, D. J. PENDLEBURY, M. LEIGHTON, J.GOLD: Is measurement of placental function and maternal weight worth while? Lancet I (1978) 1001

[10] GRUDZINSKAS, J. G., Y. B. GORDON, J. DA VIES HUMPHREYS, M. BRUDENELL, T. CHARD: Circulating levels of pregnancy specific $\beta_{1}$ glycoprotein in pregnancies complicated by diabetes mellitus. Brit. J. Obstet. Gynaec. 86 (1979) 978

[11] HAGBERG, B.: Pre-, peri- and postnatal prevention of major neuropediatric handicaps. Neuropädiatrie 6 (1975) 331

[12] HORNE, C. H. W., C. M. TOWLER, R. G. P. PUGHHUMPHREYS, A. W. THOMSON, H. BOHN: Pregnancy-specific $\beta_{1}$-glycoprotein - a product of the syncy tiotrophoblast. Experientia 32 (1976) 1197

[13] JOHANNSEN, R., H. HAUPT, H. BOHN, K. HEIDE, F. R. SEILER, H. G. SCHWICK: Inhibition of the mixed leukocyte culture (MLC) by proteins: mechanism and specificity of the reaction. Z. Immunol. Forsch. 152 (1976) 280

[14] JOSIMOVICH, J. B.: Human placental lactogen. In: FUCHS, F., A. KLOPPER (eds.): Endocrinology of pregnancy. Harper and Row, New York-EvanstonLondon 1977

[15] KEIRSE, M. J. N. C.: Aethiology of intrauterine growth retardation. In: VAN ASSCHE, F.A., W. B. ROBERTSON (eds.): Fetal growth retardation. Churchill Livingstone, Edinburgh-LondonMelbourne-New York 1981

[16] LINDBERG, B. S., B. A. NILSSON: Human placental lactogen (HPL) levels in abnormal pregnancies. $J$. Obstet. Gynaecol. Brit. Cwlth. 80 (1973) 1046

[17] LiNDBERG, B. S., E. D. B. JOHANSSON, B. A. NILSSON: Plasma levels of non-conjugated oestradiol-17 $\beta$ and oestriol in high risk pregnancies. Acta Obstet. Gynecol. Scand. Suppl. 32 (1974) 37

[18] MCCARTNEY, C. P.: Toxemias of pregnancy. In: GREENHILL, J.P. (ed.): Obstetrics, 13th ed. Saunders, Philadelphia 1965
[19] MARBLE, A., P. WHITE, R. F. BRADLEY, L. P. KRALL: Joslin's diabetes mellitus. Lea and Febiger, Philadelpha 1971

[20] NIELSEN, P. V., H. PEDERSEN, E.-M. KAMPMANN: Absence of human placental lactogen in an otherwise uneventful pregnancy. Amer. J. Obstet. Gynec. 135 (1979) 322

[21] Official Statistics for Sweden. Medical birth registration in 1973 and 1974. Statistical Report. HS 1977: 16. National Center Bureau of Statistics, Stockholm 1977

[22] PLUTA, M., W. HARDT, K. SCHMIDT-GOLLWITZER, M. SCHMIDT-GOLLWITZER: Radioimmunoassay of serum $S_{1}$ and HPL in normal and abnormal pregnancies. Arch. Gynecol. 227 (1979) 327

[23] SABBAGHA, R. E.: Fetal growth. In: ZUSPAN, F. (ed.): Ultrasound in high-risk obstetrics. Lea and Febiger, Philadelphia 1979

[24] TAMSEN, L., M. INGAN ÄS, S. G. O. JOHANSSON, B. KJESSLER, B. VON SCHOULTZ: Pregnancyspecific $\beta_{1}$ glycoprotein, $\mathrm{SP}_{1}$, in maternal serum during uncomplicated single pregnancies. Acta Universitatis Upsaliensis. Doctorae thesis, University of Uppsala 1982

[25] TATRA, G., G. BRETENECKER, W. GRUBER: Serum concentration of pregnancy-specific $\beta-1$ glycoprotein (SP-1) in normal and pathologic pregnancies. Arch. Gynecol. 217 (1974) 383

[26] TATRA, G., P. PLACHETA, G. BREITENECKER: Schwangerschaftsspezifisches $\quad \beta_{1}$-Glykoprotein (SP-1): Klinische Aspekte. Wien: Klin. Wschr. 87 (1975) 279

[27] TOWLER, C. M., V. JANDIAL, C. H. W. HORNE, H. BOHN: A serial study of pregnancy proteins in primigravidae. Brit. J. Obstet. Gynaec. 83 (1976) 368

[28] TOWLER, C. M., C. H. W. HORNE, V. JANDIAL, D. M. CAMPBELL, I. MCGILLIVRAY: Plasma levels of pregnancy-specific $\beta_{1}$-gly coprotein in complicated pregnancies. Brit. J. Obstet. Gynaec. 84 (1977) 258

[29] WESTIN, B.: Gravidogram and fetal growth. Acta Obstet. Gynecol. Scand. 56 (1977) 273

Received July 20, 1982. Accepted September 17, 1982.

Dr. L. Tamsen

Dept. of Obstetrics and Gynecology

University Hospital

S-750 14 Uppsala

Sweden 